\title{
SISTEM PENJADWALAN PERKULIAHAN MENGGUNAKAN ALGORITMA PARTICLE SWARM OPTIMIZATION PADA JURUSAN TEKNOLOGI INFORMASI FAKULTAS TEKNIK UNIVERSITAS TADULAKO
}

\section{Lecture Scheduling System Using Particle Swarm Optimization Algorithm At Department Of Information Technology Faculty Of Engineering Tadulako University}

\author{
Deny Wiria Nugraha ${ }^{1}$, A. Y. Erwin Dodu ${ }^{2}$, Muhammad Fairus B. Paloloang ${ }^{3}$ \\ 1,2,3 Jurusan Teknologi Informasi, Fakultas Teknik, Universitas Tadulako \\ e-mail: ${ }^{1}$ deny.wiria.nugraha@gmail.com, ${ }^{2}$ ayerwin.dodu@gmail.com, ${ }^{3}$ fairuzpaloloang@gmail.com
}

\begin{abstract}
Scheduling lectures is a very important activity to do because all teaching and learning activities depend on the schedule so that it must be done correctly in order not to interfere the teaching and learning activities between lecturers and students. This study aims to implement the Particle Swarm Optimization algorithm to create a scheduling system for the lectures at the Information Technology Department, Faculty of Engineering, Tadulako University which can facilitate the scheduling process of the lectures and can produce optimal schedules. The scheduling system made will follow the rules and policies which are applied at Tadulako University. The Particle Swarm Optimization algorithm can be used for scheduling system for the lectures at the Information Technology Department, Faculty of Engineering, Tadulako University, although it cannot yet produce an optimal solution because there are still soft constraints that are violated. The best combination of parameter values in the Particle Swarm Optimization algorithm, namely the parameter value $w=0.7, c 1=1.5, c 2=1.5$ with a successful schedule made with a fitness value of 0.034 with execution time (214).
\end{abstract}

Keywords - Lecture Scheduling, Course, Particle Swarm Optimization Algorithm

\section{Pendahuluan}

Dalam setiap institusi pendidikan terdapat proses penjadwalan kegiatan belajar mengajar yang dilakukan setiap awal tahun akademik untuk mengatur segala kegiatan tersebut. Dalam penyusunan jadwal perkuliahan harus dilakukan dengan benar karena jadwal tersebut akan mengatur segala kegiatan belajar mengajar antar dosen dan mahasiswa agar nantinya tidak mengganggu kegiatan tersebut. Selama ini, proses penjadwalan perkuliahan di Jurusan Teknologi Informasi Fakultas Teknik Universitas Tadulako dilakukan secara manual sehingga sering terjadi benturan antar mata kuliah yang mengakibatkan proses perkuliahan terganggu [1]-[3].

Dalam melakukan penjadwalan perkuliahan harus memperhatikan ketersediaan jumlah dosen dan ruang yang ada, waktu mengajar setiap dosen yang tidak boleh sama, dan lain-lain sehingga jadwal perkuliahan yang optimal akan sangat sulit untuk didapatkan. Oleh sebab itu, dibutuhkan suatu sistem yang dapat menggantikan proses manual tersebut menjadi lebih praktis sehingga menghasilkan jadwal perkuliahan yang lebih optimal dengan waktu yang lebih singkat. Algoritma 
Particle Swarm Optimization (PSO) merupakan salah satu algoritma yang dapat digunakan untuk membuat sistem tersebut.

\section{Landasan Teori}

Penjadwalan adalah proses pengambilan keputusan yang mempunyai peran penting dalam proses manufaktur dan sistem produksi begitu juga dalam lingkungan pemrosesan informasi. Penjadwalan juga terdapat dalam transportasi dan distribusi serta dalam industri [4]. Dalam pembuatan jadwal mata kuliah harus memperhatikan dua kategori batasan/persyaratan, yaitu batasan pokok (hard constraint) dan batasan lunak (soft constraint) [5].

Algoritma optimasi bisa dikatakan sebagai generalisasi dari algoritma pencarian atau dengan kata lain, algoritma pencarian adalah kasus khusus dari algoritma optimasi [6]. Hasil dari suatu proses optimasi adalah suatu himpunan masukan yang membuat fungsi-fungsi objektif menghasilkan nilai-nilai optimal (yang bisa berupa maksimal atau minimal). Dari beberapa algoritma optimasi yang ada, algoritma PSO dapat digunakan untuk menyelesaikan masalah optimasi yang sulit.

Proses algoritma PSO terinspirasi oleh tingkah laku sosial pada kawanan burung yang terbang bersama-sama. Perilaku sosial ini terdiri dari tindakan individu dan pengaruh dari individuindividu lain dalam suatu kelompok. Jika satu partikel atau seekor burung menemukan jalan yang tepat atau optimal menuju sumber makanan, maka sisa anggota kelompok yang lainnya juga akan mengikuti jalan tersebut meskipun lokasi mereka didalam kelompok tersebut tidak saling berdekatan [7]. Dalam PSO populasi disebut dengan swarm, dan individu disebut dengan partikel. Algoritma dasar PSO terdiri dari tiga tahap, yaitu pembangkitan posisi serta kecepatan partikel, update kecepatan, dan update posisi. Posisi $x_{k}^{i}$ dan kecepatan $v_{k}^{i}$ dari kumpulan partikel dibangkitkan secara random menggunakan batas atas $x_{\max }$ dan batas bawah $x_{\min }$ dari design variabel, seperti yang ditunjukkan pada persamaan (1) dan (2).

$$
\begin{aligned}
& x_{0}^{i}=x_{\text {min }}+\operatorname{rand}\left(x_{\max }-x_{\text {min }}\right) \\
& v_{0}^{i}=x_{\text {min }}+\operatorname{rand}\left(x_{\text {max }}-x_{\text {min }}\right)
\end{aligned}
$$

Langkah kedua adalah update kecepatan pada semua partikel dengan menggunakan nilai fitness posisi partikel saat ini. Dari nilai fitness dapat ditentukan partikel mana yang mempunyai nilai global terbaik pada swarm saat ini $p_{k}^{g}$ dan juga dapat ditentukan posisi terbaik dari setiap partikel pada semua waktu yang sekarang dan sebelumnya $p^{i}$. Perumusan update kecepatan menggunakan dua informasi tersebut untuk semua partikel pada kumpulan dengan pengaruh perpindahan yang sekarang $v_{k}^{i}$ untuk memberikan arah pencarian $v_{k+1}^{i}$ untuk generasi selanjutnya. Perumusan update kecepatan mencakup beberapa parameter random (rand), untuk mendapatkan cakupan yang baik, tiga parameter yang mempengaruhi arah pencarian, yaitu inertia factor $w$, self confidence c1, dan swarm confidence c2 seperti yang ditunjukkan persamaan (3).

$$
v_{k+1}^{i}=w * v_{k}^{i}+c 1 * \operatorname{rand} *\left(p^{i}-x_{k}^{i}\right)+c 2 * \operatorname{rand} *\left(p_{k}^{g}-x_{k}^{i}\right)
$$


Langkah terakhir dari setiap iterasi adalah update posisi setiap partikel dengan vektor velocity, seperti yang ditunjukkan pada persamaan (4).

$$
x_{k+1}^{i}=x_{k}^{i}+v_{k+1}^{i}
$$

Tiga tahapan diatas akan diulang sampai kriteria stopping condition dari algoritma terpenuhi, yaitu ketika algoritma sudah sampai pada iterasi maksimum atau algoritma sudah mendapatkan nilai optimum tertentu yang diinginkan.

\section{Metode Penelitian}

\subsection{Pengumpulan Data}

Melakukan wawancara secara langsung kepada pihak-pihak yang terlibat dalam sistem penjadwalan perkuliahan yang dibangun. Wawancara dilakukan untuk mendapatkan informasi tentang data mata kuliah, data dosen, data ruang, dan data waktu aktif kuliah. Penelitian tentang pembuatan sistem penjadwalan perkuliahan ini dilakukan pada Jurusan Teknologi Informasi Fakultas Teknik Universitas Tadulako. Langkah-langkah dalam membangun sistem perkuliahan dapat diuraikan sebagai berikut:

1. Tahap pengumpulan data adalah melakukan pengambilan data secara langsung ke lapangan dengan melakukan wawancara secara langsung kepada pihak-pihak yang terlibat dalam sistem penjadwalan perkuliahan yang dibangun.

2. Wawancara dilakukan untuk mendapatkan informasi tentang data mata kuliah, data dosen, data ruang, dan data waktu aktif kuliah. Pada tahap ini berdasarkan data yang diperoleh, batasan-batasan penjadwalan perkuliahan telah ditentukan, adalah seperti berikut:

- Batasan Keras

a. Pada satu ruangan kuliah hanya dapat menyelenggarakan satu mata kuliah pada slot waktu yang sama.

b. Mata kuliah dengan semester yang sama tidak boleh dijadwalkan pada waktu yang sama dan ruang yang berbeda.

- Batasan Lunak

a. Seorang dosen dapat memilih hari dan periode waktu yang tidak disukai berdasarkan timeslot yang tersedia.

b. Seorang dosen tidak boleh dijadwalkan lebih dari satu kali pada waktu yang sama.

\subsection{Lokasi Penelitian}

Dalam pembuatan sistem penjadwalan perkuliahan ini, penulis melakukan penelitian di Jurusan Teknologi Informasi Fakultas Teknik Universitas Tadulako.

\subsection{Perancangan Perangkat Lunak}

Tahap perancangan perangkat lunak adalah melakukan perancangan kebutuhan perangkat lunak dan tahapan-tahapan proses operasi aplikasi mencakup proses penerapan PSO pada sistem penjadwalan perkuliahan. Flowchart algoritma PSO dapat dilihat pada Gambar 1. 


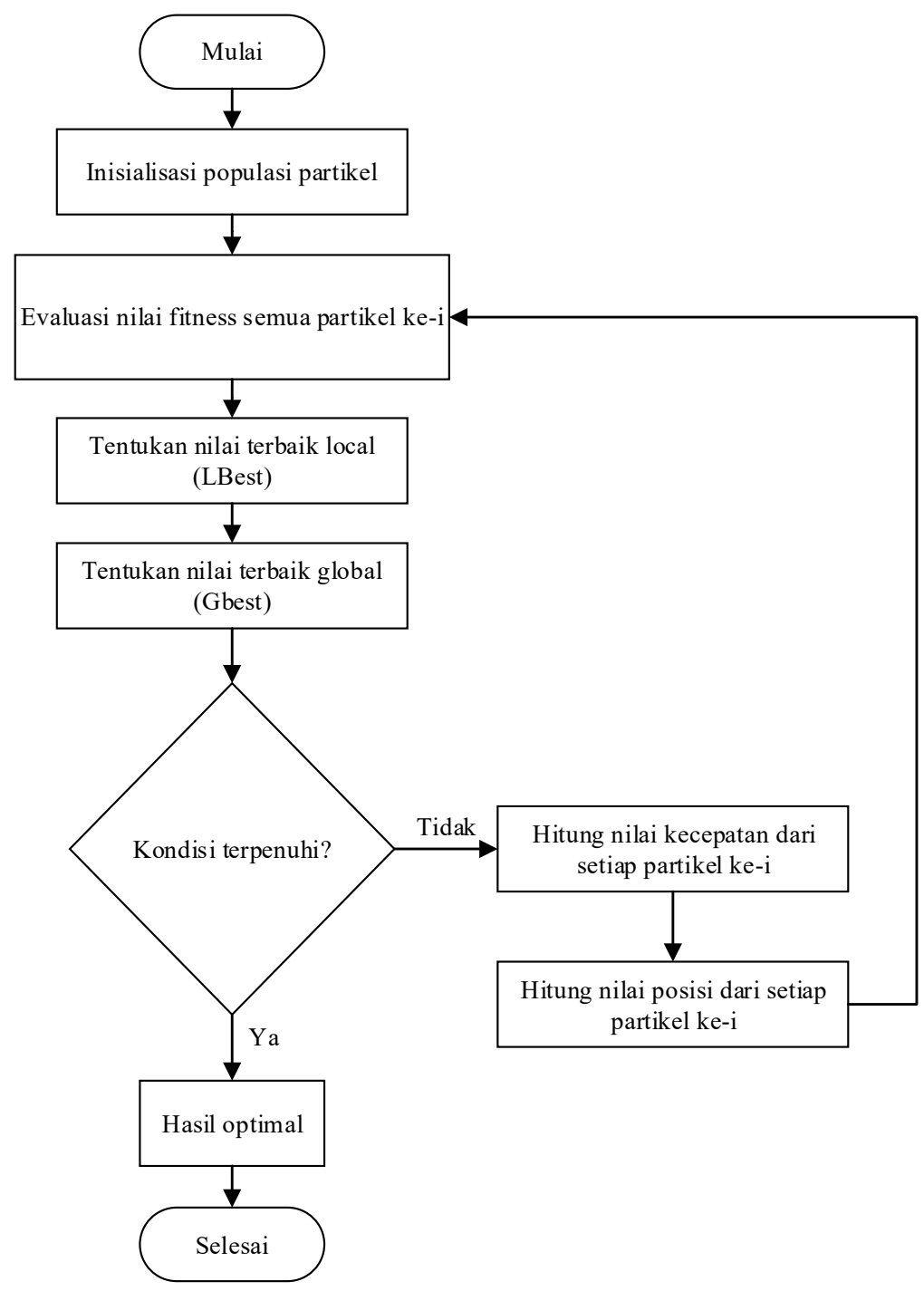

Gambar 1. Flowchart Algoritma PSO

\subsection{Pembuatan Perangkat Lunak}

Tahap pembuatan perangkat lunak adalah melakukan implementasi pada tahap perancangan perangkat lunak dengan melakukan persiapan software yang digunakan, membuat desain interface, dan melakukan penulisan program.

\subsection{Pengujian Perangkat Lunak}

Pada tahap ini dilakukan pengujian perangkat lunak yang meliputi kemampuan sistem dalam menyelesaikan masalah penjadwalan dengan baik. Pengujian akan dilakukan dengan menguji kombinasi parameter inertia weight $w, c 1$ dan $c 2$ beserta partikel yang dapat menghasilkan jadwal yang paling baik. Pengujian ini dilakukan sebanyak 4 kali dengan setiap kombinasi parameter PSO yang berbeda-beda. 


\section{Pembahasan Dan Hasil}

\subsection{Sistem Penjadwalan Perkuliahan}

Penelitian ini menghasilkan sistem penjadwalan perkuliahan berbasis dekstop. Pada sistem ini terdapat form input dosen mata kuliah yang digunakan untuk memasukkan dosen mata kuliah sebagai informasi dalam proses penjadwalan. Form input dosen mata kuliah dapat dilihat seperti pada gambar 2 .

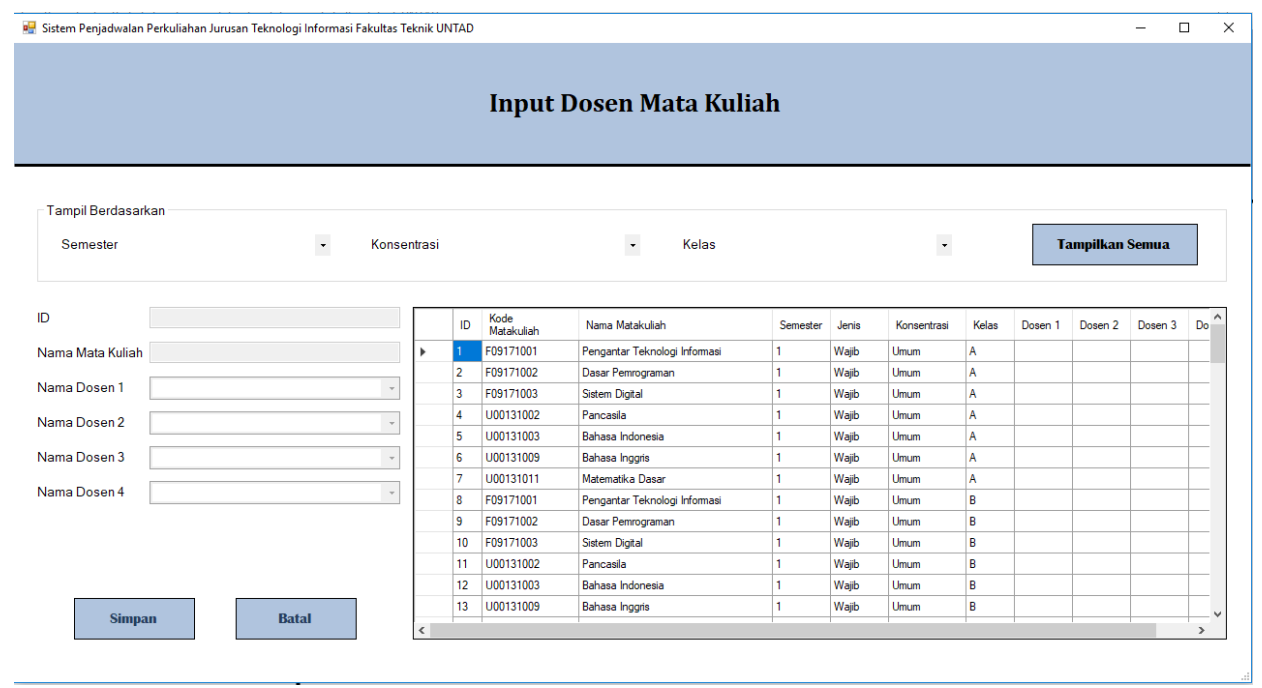

Gambar 2. Form Dosen Mata Kuliah

Setelah semua informasi yang dibutuhkan oleh sistem dimasukkan, klik tombol buat jadwal untuk memulai proses pembuatan jadwal. Hasil proses penjadwalan dapat dilihat pada Gambar 3.

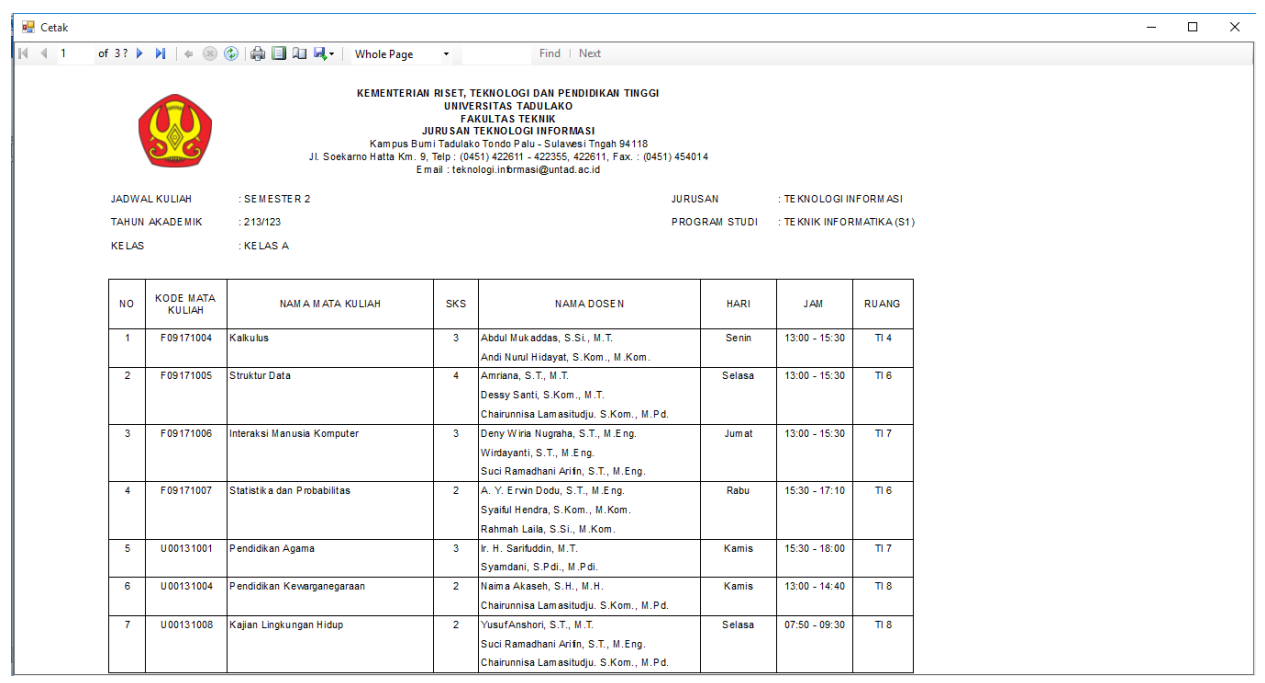

\section{Gambar 3. Hasil Cetak Jadwal}

Untuk menampilkan daftar pelanggaran dari hasil proses penjadwalan dapat dilihat pada form daftar pelanggaran. Gambar form daftar pelanggaran dapat dilihat pada Gambar 4 . 


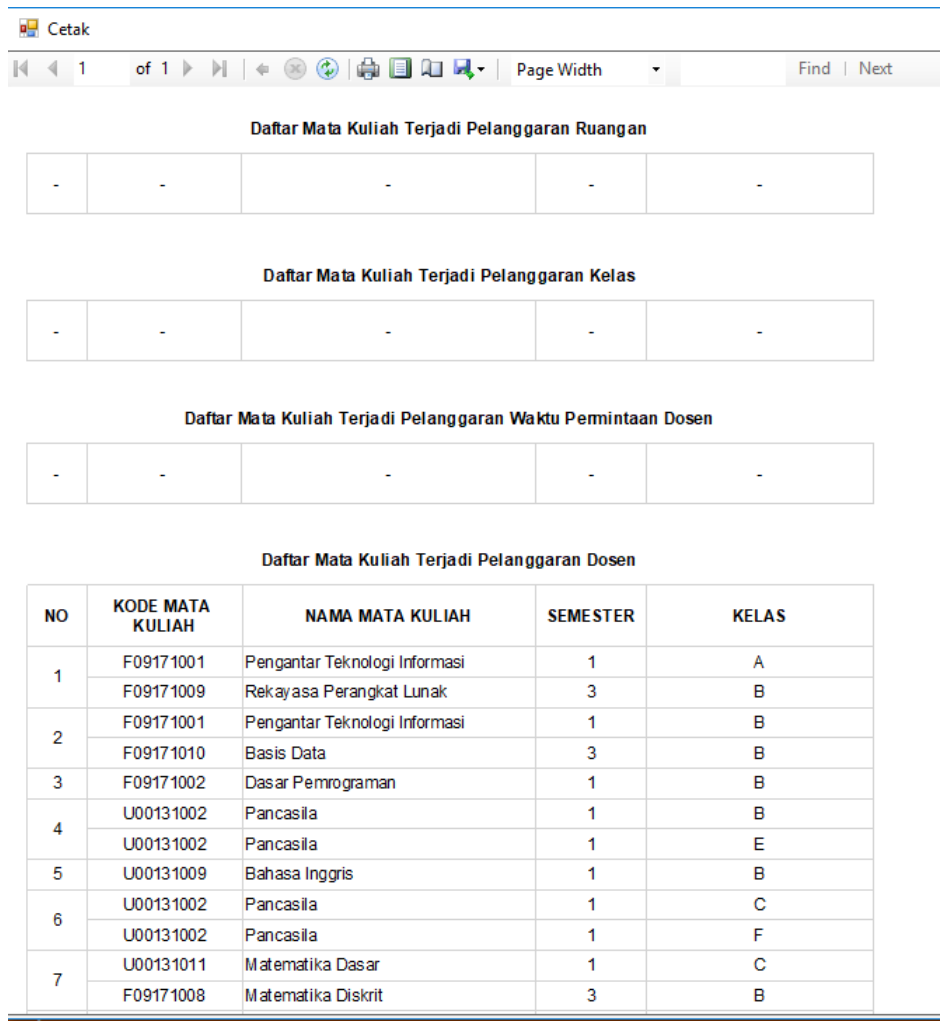

Gambar 4. Daftar Pelanggaran

\subsection{Implementasi Algoritma Particle Swarm Optimization}

\subsubsection{Membangkitkan Posisi dan Kecepatan Partikel}

Untuk membangkitkan posisi dan kecepatan partikel digunakan persamaan (1) dan (2). Partikel yang akan digunakan sebanyak 100 partikel. Dalam pembangkitan posisi dan kecepatan partikel tersebut diperlukan data-data yang digunakan untuk proses pembuatan jadwal semester genap 2017/2018. Berikut data-data yang dibutuhkan dapat dilihat pada Tabel 1.

Tabel 1. Data-data Penjadwalan

\begin{tabular}{|c|c|c|}
\hline No. & Keterangan & Jumlah \\
\hline 1 & Total mata kuliah pada semester genap & 26 \\
\hline 2 & Total dosen & 24 \\
\hline 3 & Total kelas semester 2 & 6 \\
\hline 4 & Total kelas semester 4 & 4 \\
\hline 5 & Total kelas semester 6 umum & 2 \\
\hline 6 & Total kelas semester 6 RPL & 2 \\
\hline 7 & Total kelas semester 6 SC & 1 \\
\hline 8 & Ruangan yang tersedia & 8 \\
\hline 9 & Hari per minggu & 5 \\
\hline 10 & Slot jam per hari & 3 \\
\hline
\end{tabular}




\subsubsection{Evaluasi Fungsi Fitness}

Nilai fitness dihitung sesuai dengan total jumlah pelanggaran yang dilakukan, untuk setiap pelanggaran untuk kategori batasan keras diberi penalti 1 dan batasan lunak penalti 0.001 . Tabel 2 menunjukkan kategori jenis batasan pelanggaran.

Tabel 2. Kategori Jenis Batasan Pelanggaran

\begin{tabular}{|c|c|}
\hline Kode Batasan & Jenis Batasan \\
\hline Pelanggaran Ruangan (PR) & Batasan Keras \\
\hline Pelanggaran Kelas (PK) & Batasan Keras \\
\hline Pelanggaran Dosen (PD) & Batasan Lunak \\
\hline Pelanggaran Waktu Permintaan Dosen (PWPD) & Batasan Lunak \\
\hline
\end{tabular}

\subsubsection{Menentukan Local Best dan Global Best}

Untuk menentukan local best $p^{i}$ dilakukan dengan cara membandingkan nilai fitness yang dimiliki partikel sekarang dengan nilai fitness pada local best. Jika nilai fitness yang dimiliki partikel sekarang lebih kecil dari nilai fitness pada local best, maka local best akan di update dengan nilai posisi sekarang. Untuk iterasi pertama, local best sama dengan posisi awal partikel.

Setelah didapatkan local best, maka selanjutnya menentukan partikel global terbaik $p^{g}$ dengan membandingkan nilai fitness dari setiap local best. Partikel yang memiliki nilai fitness terkecil akan disimpan sebagai global best.

\subsubsection{Update Kecepatan dan Posisi}

Untuk melakukan update kecepatan kita akan menggunakan persamaan (5) dan untuk update posisi kita akan menggunakan persamaan (6). Untuk ketiga parameter pada persamaan (5) akan digunakan $\mathrm{w}=0.7, \mathrm{c} 1=1.5$, dan $\mathrm{c} 2=1.5$

\subsubsection{Stopping Condition}

Untuk stopping condition dalam penjadwalan perkuliahan yaitu jika nilai fitness terbaik telah tercapai artinya tidak ada pelanggaran yang terjadi, atau jika maksimal iterasi telah tercapai. Setelah dilakukan proses pembuatan jadwal menggunakan algoritma PSO, maka hasilnya seperti yang terlihat pada tabel 3 .

Tabel 3. Hasil Pembuatan Jadwal

\begin{tabular}{|c|c|c|c|c|c|c|c|}
\hline \multirow[t]{2}{*}{ Iterasi } & \multirow[t]{2}{*}{ Partikel } & \multicolumn{4}{|c|}{ Pelanggaran } & \multirow[t]{2}{*}{ Fitness } & \multirow{2}{*}{$\begin{array}{c}\text { Waktu } \\
\text { Eksekusi }\end{array}$} \\
\hline & & PR & PK & PD & PWPD & & \\
\hline 2642 & 26 & 0 & 0 & 0.034 & 0 & 0.034 & 214 detik \\
\hline
\end{tabular}


Dapat dilihat bahwa dari hasil yang telah didapat belum menghasilkan solusi yang optimal, karena masih terdapat pelanggaran (PWPD), namun jika tanpa memperhatikan soft constraint, maka dapat menghasilkan solusi yang optimal, dimana solusi terbaik dengan nilai fitness 0.034 dengan menggunakan parameter $\mathrm{w}=0.7, \mathrm{c} 1=1.5, \mathrm{c} 2=1.5$ dan maksimal iterasi 5000

\subsection{Pengujian Sistem}

Pengujian sistem penjadwalan perkuliahan menggunakan algoritma PSO ini dilakukan dengan menguji kombinasi parameter inertia weight (w), c1 dan c2 beserta partikel yang dapat menghasilkan jadwal yang paling baik. Pengujian ini dilakukan sebanyak 4 kali untuk mendapatkan kombinasi parameter PSO yang baik untuk sistem ini.

\subsubsection{Nilai Parameter $w=0.3, c 1=2, c 2=2$}

Untuk pengujian kombinasi parameter pertama digunakan nilai parameter $\mathrm{w}=0.3, \mathrm{c} 1=2, \mathrm{c} 2=2$, dengan jumlah partikel yaitu 20, 50, 100 dan iterasi maksimum 5000. Hasil dari pengujian kombinasi parameter yang pertama dapat dilihat pada tabel 4.

Tabel 4. Hasil Dari Pengujian Kombinasi Parameter Yang Pertama

\begin{tabular}{|c|c|c|c|c|c|c|c|c|}
\hline No. & $\begin{array}{c}\text { Jumlah } \\
\text { Partikel }\end{array}$ & Iterasi & Partikel & \multicolumn{3}{|c|}{ Pelanggaran } & Fitness & $\begin{array}{c}\text { Waktu } \\
\text { Eksekusi }\end{array}$ \\
\hline & & & & Ruangan & Kelas & Dosen & & \\
\hline 1 & 20 & 1875 & 16 & 5 & 0 & 0.046 & 5.046 & 60 detik \\
\hline 2 & 20 & 4714 & 20 & 6 & 0 & 0.054 & 6.054 & 66 detik \\
\hline 3 & 20 & 4026 & 2 & 8 & 1 & 0.047 & 9.047 & 62 detik \\
\hline \multicolumn{7}{|c|}{ Rata-rata } \\
\hline 4 & 50 & 1400 & 27 & 3 & 0 & 0.042 & 3.042 & 112 detik \\
\hline 5 & 50 & 4212 & 16 & 3 & 0 & 0.044 & 3.044 & 107 detik \\
\hline 6 & 50 & 2528 & 8 & 4 & 0 & 0.039 & 4.039 & 112 detik \\
\hline \multicolumn{7}{|c|}{ Rata-rata } \\
\hline 7 & 100 & 3475 & 67 & 1 & 1 & 0.032 & 2.032 & 199 detik \\
\hline 8 & 100 & 4782 & 18 & 4 & 0 & 0.036 & 4.036 & 178 detik \\
\hline 9 & 100 & 2016 & 72 & 1 & 0 & 0.039 & 1.039 & 178 detik \\
\hline \multicolumn{7}{|c|}{ Rata-rata } \\
\hline \multicolumn{7}{|c|}{ Rata-rata keseluruhan } & \\
\hline
\end{tabular}

Berdasarkan dari hasil pengujian kombinasi parameter yang dapat dilihat pada tabel 4 yaitu pada pengujian nomor 7 sampai 9 yang jumlah partikelnya 100 mendapatkan nilai rata-rata fitness yang paling baik yaitu 2.369, walaupun waktu eksekusinya cenderung lebih lama dengan rata-rata 185 detik.

\subsubsection{Nilai Parameter $w=0.5, c 1=1.5, c 2=1.5$}

Untuk pengujian kombinasi parameter kedua digunakan nilai parameter $\mathrm{w}=0.5, \mathrm{c} 1=1.5$, c2 $=1.5$, dengan jumlah partikel yaitu 20,50, 100 dan iterasi maksimum 5000. Hasil dari pengujian kombinasi parameter yang kedua dapat dilihat pada tabel 5 .

Tabel 5. Hasil Dari Pengujian Kombinasi Parameter Yang Kedua

\begin{tabular}{|c|c|c|c|c|c|c|}
\hline No. & $\begin{array}{c}\text { Jumlah } \\
\text { Partikel }\end{array}$ & Iterasi & Partikel & Pelanggaran & Fitness & $\begin{array}{c}\text { Waktu } \\
\text { Eksekusi }\end{array}$ \\
\hline
\end{tabular}




\begin{tabular}{|c|c|c|c|c|c|c|c|c|}
\hline & & & Ruangan & Kelas & Dosen & & \\
\hline 1 & 20 & 429 & 16 & 8 & 0 & 0.049 & 8.049 & 56 detik \\
\hline 2 & 20 & 4176 & 8 & 8 & 1 & 0.06 & 9.06 & 55 detik \\
\hline 3 & 20 & 261 & 5 & 8 & 1 & 0.058 & 9.058 & 55 detik \\
\hline \multicolumn{7}{|c|}{ Rata-rata } & 5.722 & 55 detik \\
\hline 4 & 50 & 430 & 5 & 7 & 0 & 0.045 & 7.045 & 101 detik \\
\hline 5 & 50 & 1295 & 21 & 3 & 1 & 0.06 & 4.06 & 101 detik \\
\hline 6 & 50 & 344 & 4 & 4 & 1 & 0.046 & 5.046 & 107 detik \\
\hline \multicolumn{7}{|c|}{ Rata-rata } \\
\hline 7 & 100 & 1656 & 80 & 6 & 0 & 0.045 & 6.045 & 173 detik \\
\hline 8 & 100 & 1109 & 93 & 4 & 0 & 0.048 & 4.048 & 212 detik \\
\hline 9 & 100 & 1638 & 83 & 4 & 1 & 0.05 & 5.05 & 200 dtik \\
\hline \multicolumn{7}{|c|}{ Rata-rata } \\
\hline \multicolumn{7}{|c|}{ Rata-rata keseluruhan }
\end{tabular}

Berdasarkan dari hasil pengujian kombinasi parameter yang dapat dilihat pada tabel 5 yaitu pada pengujian nomor 7 sampai 9 yang jumlah partikelnya 100 mendapatkan nilai rata-rata fitness yang paling baik yaitu 5.048, walaupun waktu eksekusinya cenderung lebih lama dengan rata-rata 195 detik.

\subsubsection{Nilai Parameter $w=0.7, c 1=1.5, c 2=1.5$}

Untuk pengujian kombinasi parameter ketiga digunakan nilai parameter $\mathrm{w}=0.7, \mathrm{cl}=1.5$, c2 $=1.5$, dengan jumlah partikel yaitu 20,50, 100 dan iterasi maksimum 5000. Hasil dari pengujian kombinasi parameter yang ketiga dapat dilihat pada tabel 6 .

Tabel 6. Hasil Dari Pengujian Kombinasi Parameter Yang Ketiga

\begin{tabular}{|c|c|c|c|c|c|c|c|c|}
\hline \multirow[t]{2}{*}{ No. } & \multirow[t]{2}{*}{$\begin{array}{l}\text { Jumlah } \\
\text { Partikel }\end{array}$} & \multirow[t]{2}{*}{ Iterasi } & \multirow[t]{2}{*}{ Partikel } & \multicolumn{3}{|c|}{ Pelanggaran } & \multirow[t]{2}{*}{ Fitness } & \multirow[t]{2}{*}{$\begin{array}{c}\text { Waktu } \\
\text { Eksekusi }\end{array}$} \\
\hline & & & & Ruangan & Kelas & Dosen & & \\
\hline 1 & 20 & 2098 & 20 & 0 & 0 & 0.053 & 0.053 & 72 detik \\
\hline 2 & 20 & 2381 & 2 & 4 & 0 & 0.06 & 4.06 & 65 detik \\
\hline 3 & 20 & 4744 & 6 & 3 & 0 & 0.049 & 3.049 & 70 detik \\
\hline \multicolumn{7}{|c|}{ Rata-rata } & 2.387 & 69 detik \\
\hline 4 & 50 & 4803 & 20 & 0 & 0 & 0.038 & 0.038 & 113 detik \\
\hline 5 & 50 & 2266 & 10 & 0 & 1 & 1.05 & 1.05 & 110 detik \\
\hline 6 & 50 & 3855 & 16 & 1 & 1 & 0.054 & 2.054 & 103 detik \\
\hline \multicolumn{7}{|c|}{ Rata-rata } & 1.047 & 108 detik \\
\hline 7 & 100 & 2642 & 26 & 0 & 0 & 0.034 & 0.034 & 214 detik \\
\hline 8 & 100 & 1816 & 61 & 1 & 0 & 0.037 & 1.037 & 228 detik \\
\hline 9 & 100 & 1235 & 85 & 0 & 0 & 0.044 & 0.044 & 216 detik \\
\hline \multicolumn{7}{|c|}{ Rata-rata } & 0.372 & 219 detik \\
\hline \multicolumn{7}{|c|}{ Rata-rata keseluruhan } & 1.269 & 132 detik \\
\hline
\end{tabular}

Berdasarkan dari hasil pengujian kombinasi parameter yang dapat dilihat pada tabel 6 yaitu pada pengujian nomor 7 sampai 9 yang jumlah partikelnya 100 mendapatkan nilai rata-rata fitness yang paling baik yaitu 0.372 , walaupun waktu eksekusinya cenderung lebih lama dengan rata-rata 219 detik. 


\subsubsection{Nilai Parameter $\mathrm{w}=0.7, \mathrm{c} 1=1.5, \mathrm{c} 2=2$}

Untuk pengujian kombinasi parameter keempat digunakan nilai parameter $\mathrm{w}=0.7, \mathrm{c} 1=1.5$, c2 $=2$, dengan jumlah partikel yaitu 20, 50, 100 dan iterasi maksimum 5000. Hasil dari pengujian kombinasi parameter yang keempat dapat dilihat pada tabel 4.13.

Tabel 7. Hasil Dari Pengujian Kombinasi Parameter Yang Keempat

\begin{tabular}{|c|c|c|c|c|c|c|c|c|}
\hline No. & $\begin{array}{c}\text { Jumlah } \\
\text { Partikel }\end{array}$ & Iterasi & Partikel & \multicolumn{3}{|c|}{ Pelanggaran } & Fitness & $\begin{array}{c}\text { Waktu } \\
\text { Eksekusi }\end{array}$ \\
\hline & & & & Ruangan & Kelas & Dosen & & \\
\hline 1 & 20 & 3852 & 6 & 8 & 0 & 0.037 & 8.037 & 60 detik \\
\hline 2 & 20 & 4286 & 5 & 4 & 0 & 0.039 & 4.039 & 55 detik \\
\hline 3 & 20 & 2712 & 18 & 6 & 0 & 0.053 & 6.053 & 67 detik \\
\hline \multicolumn{7}{|c|}{ Rata-rata } \\
\hline 4 & 50 & 4193 & 30 & 2.04 & 0 & 0.04 & 2.04 & 110 detik \\
\hline 5 & 50 & 4820 & 2 & 7 & 1 & 0.035 & 8.035 & 121 detik \\
\hline 6 & 50 & 4987 & 29 & 7 & 0 & 0.044 & 7.044 & 116 detik \\
\hline \multicolumn{7}{|c|}{ Rata-rata } \\
\hline 7 & 100 & 3209 & 20 & 5 & 0 & 0.033 & 5.033 & 198 detik \\
\hline 8 & 100 & 3745 & 67 & 6 & 0 & 0.034 & 6.034 & 208 detik \\
\hline 9 & 100 & 4532 & 68 & 1 & 0 & 0.043 & 1.043 & 179 detik \\
\hline \multicolumn{7}{|c|}{ Rata-rata } \\
\hline \multicolumn{8}{|c|}{ Rata-rata keseluruhan } & \\
\hline
\end{tabular}

Berdasarkan dari hasil pengujian kombinasi parameter yang dapat dilihat pada tabel 7 yaitu pada pengujian nomor 7 sampai 9 yang jumlah partikelnya 100 mendapatkan nilai rata-rata fitness yang paling baik yaitu 4.037, walaupun waktu eksekusinya cenderung lebih lama dengan rata-rata 195 detik.

Berdasarkan hasil pengujian dari 4 pengujian parameter yang telah dilakukan menunjukkan bahwa pengujian ketiga dengan nilai parameter $\mathrm{w}=0.7, \mathrm{c} 1=1.5, \mathrm{c} 2=1.5$ mendapatkan nilai ratarata keseluruhan fitness yang paling baik diantara 3 parameter yang lainnya yaitu sebesar 1.269. Kemudian dari keempat pengujian paramater tersebut dapat diketahui bahwa semakin besar jumlah partikel yang digunakan, maka peluang untuk mendapatkan nilai fitness yang baik semakin besar tetapi waktu eksekusinya pun semakin bertambah.

\section{Kesimpulan}

Berdasarkan pengujian dan analisis sistem penjadwalan perkuliahan menggunakan algoritma PSO pada Jurusan Teknologi Informasi Fakultas Teknik Universitas Tadulako, maka dapat diperoleh kesimpulan sebagai berikut:

1. Algoritma PSO dapat digunakan untuk sistem penjadwalan perkuliahan pada Jurusan Teknologi Informasi Fakultas Teknik Universitas Tadulako.

2. Hasil yang didapat dari algoritma PSO dalam menyelesaikan penjadwalan perkuliahan belum menghasilkan solusi yang optimal, karena masih ada soft constraint yang terlanggar, namun jika tanpa memperhatikan soft constraint, maka akan menghasilkan solusi yang optimal.

3. Berdasarkan seluruh pengujian yang telah dilakukan terlihat bahwa kombinasi nilai parameter dalam algoritma PSO yang paling baik untuk sistem ini adalah nilai parameter $\mathrm{w}=0.7, \mathrm{c} 1=$ $1.5, \mathrm{c} 2=1.5$. 
4. Sistem penjadwalan dijalankan untuk membuat jadwal perkuliahan semester genap 2017/2018. Jadwal perkuliahan semester genap 2017/2018 berhasil dibuat dengan nilai fitness 0.034 dengan waktu eksekusi selama 214 detik.

\section{DAFTAR REFERENSI}

[1] A. T. S. Saud, D. W. Nugraha, and A. Y. Erwin, "Sistem Penjadwalan Perkuliahan Menggunakan Algoritma Genetika (Studi Kasus Jurusan Teknologi Informasi Fakultas Teknik Universitas Tadulako)," J. Ilm. Mat. Dan Terap., vol. 14, no. 2, (2017).

[2] W. A. Puspaningrum, A. Djunaidy, and R. A. Vinarti, "Penjadwalan Mata Kuliah Menggunakan Algoritma Genetika di Jurusan Sistem Informasi ITS," J. Tek. ITS, vol. 2, no. 1, pp. A127-A131,(2013).

[3] S. Saifullah and A. Hermawan, "Pengembangan Sistem Penjadwalan Kuliah Menggunakan Algoritma Steepest Ascent Hill Climbing,” J. Sist. Komput., vol. 6, no. 2, (2016).

[4] J. G. Suhendri, "Rancang Bangun Aplikasi Pengoptimalan Penjadwalan Praktikum Menggunakan Metode Tabu Search Pada Laboratorium Komputer Institut Bisnis dan Informatika Stikom Surabaya," Skripsi, STIKOM, Surabaya, (2016).

[5] D. A. R. Wati and Y. A. Rochman, "Model Penjadwalan Matakuliah Secara Otomatis Berbasis Algoritma Particle Swarm Optimization (PSO)," J. Rekayasa Sist. Ind., vol. 2, no. 1, pp. $22-$ 31, (2013).

[6] M. Misbahul Ilmi, "Optimasi jadwal perkuliahan menggunakan algoritma particle swarm optimization: Studi kasus Fakultas Sains dan Teknologi Universitas Islam Negeri Maulana Malik Ibrahim Malang," PhD Thesis, Universitas Islam Negeri Maulana Malik Ibrahim, (2015).

[7] G. F. Fahnani, Y. Yuningtyastuti, and S. Handoko, "Simulasi Optimasi Daya Reaktif Dan Tegangan Pada Sistem JamalI 500 kV Menggunakan Metode Particle Swarm Optimization," TRANSIENT, vol. 2, no. 2, pp. 322-328, (2013). 